\title{
Gestos de arquivo
}

\section{$\S$}

Desde o início precisei do arquivo

contra a falácia dos gestos que se acreditam

excessivamente livres e leves.

Desde o início precisei do peso

e acreditei

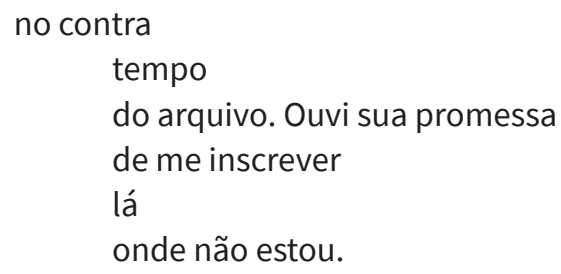

\section{$\S$}

Talvez

o despertar do arquivo

tenha sido

$$
\text { a shibolet }
$$

na fala de minha avó

incapaz de pronunciar

as duas vogais

que juntas

flexionam meu nome. 
REDE INTERNACIONAL LYRACOMPOETICS

Arquivo é nome próprio.

Nome próprio é arquivo.

$\S$

Tarefas -

localizar

no que é mais desprezado e inútil

certa potência de nome próprio

ouvir

seu apelo de imagem

sustentar

sua face, sua força de aparição

(assumir a posse

sempre provisória

do arquivo - ativar seu dom) 

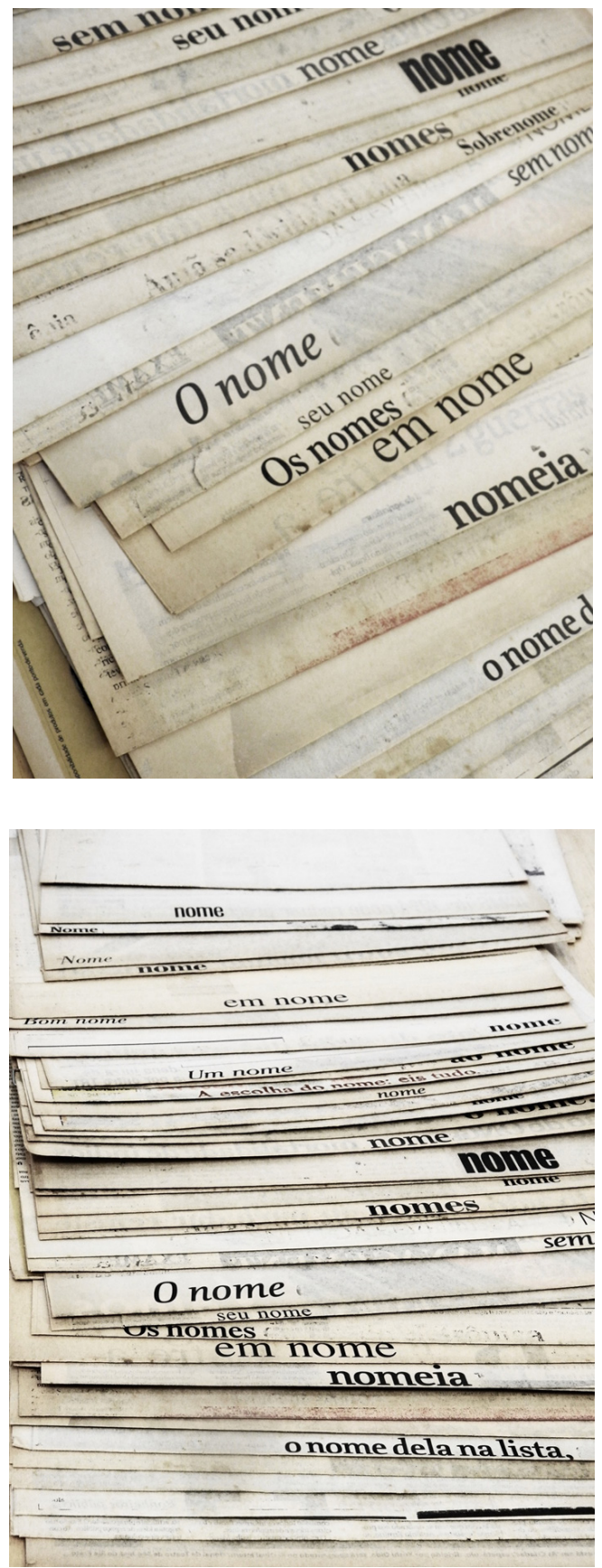


\section{NOTA}

* Leila Danziger nasceu no Rio de Janeiro, onde vive e trabalha. É artista plástica e professora associada do Instituto de Artes da Universidade do Estado do Rio de Janeiro. Apresentou a mostra individual Ao sul do futuro, no Museu Lasar Segall, em São Paulo (2018) e Navio de emigrantes, na Caixa Cultural de Brasília (2018) e de São Paulo (2019). É autora de Três ensaios de fala (2012), Ano novo (2016) e C'est loin Bagdad [fotogramas] (Coleção Megamíni, 2018) e Cinelândia (2021), todos pela 7Letras. Publicou também Diários públicos (Contracapa, 2013) e Todos os nomes da melancolia (Apicuri, 2012), que reúne ensaios de diversos autores sobre sua produção artística. 